\title{
Influence of dietary supplementation of probiotics on intestinal histo-morphometry, blood chemistry and gut health status of broiler chickens
}

\author{
A. Biswas ${ }^{1 \#}$, N. Junaid, M. Kumawat ${ }^{1}$, S. Qureshi ${ }^{2}$ \& A.B. Mandal ${ }^{1}$ \\ ${ }^{1}$ Avian Nutrition and Feed Technology Division, ICAR-Central Avian Research Institute, Izatnagar-243 122, India \\ ${ }^{2}$ Biological Standardization Division, ICAR- Indian Veterinary Research Institute, Izatnagar-243 122, India
}

(Received 31 January 2018; Accepted 1 August 2018; First published online 20 November 2018)

Copyright resides with the authors in terms of the Creative Commons Attribution 4.0 South African License. See:
http://creativecommons. org/licenses/by/4.0/za
Condition of use: The user may copy, distribute, transmit and adapt the work, but must recognize the authors and the South African
Journal of Animal Science

\begin{abstract}
The objective of this experiment was to investigate the effects of dietary supplementation of probiotics, Lactobacillus acidophilus and Bifidobacterium bifidum, on histo-morphologic measurements of the small intestine and on the gut health status of broiler chickens. A total of 240 day-old broiler chicks were randomly assigned to one of six dietary treatments for six weeks. The dietary treatments were basal diet $\left(\mathrm{T}_{1}\right)$; basal diet + bacitracin methyl di-salicylate (BMD) at $20 \mathrm{mg} / \mathrm{kg}$ diet $\left(\mathrm{T}_{2}\right)$; basal diet $+L$. acidophilus $\left(10^{6}\right.$ and $10^{7}$ cfu/gm diet) $\left(T_{3}\right.$ and $\left.T_{4}\right)$; and basal diet + B. bifidum $\left(10^{6}\right.$ and $10^{7}$ cfu/gm diet $)\left(T_{5}\right.$ and $\left.T_{6}\right)$, respectively. The villus height $(\mathrm{VH})$, width $(\mathrm{VW})$, crypt depth $(\mathrm{CD})$ and the ratio between villus height and crypt depth $(\mathrm{VH}: \mathrm{CD})$ were significantly increased at 21 days and 42 days in $L$. acidophilus-supplemented groups $\left(T_{3}\right.$ or $\left.T_{4}\right)$. No significant differences were observed in protein, albumin and serum mineral ( $\mathrm{Ca}$ and $\mathrm{P}$ ) concentrations and alkaline phosphatase (ALP) activity in any of the dietary probiotic treatment groups. Aspartate aminotransferase (AST) and creatinine concentrations were increased, whereas alanine aminotransferase (ALT), uric acid and total cholesterol levels were significantly decreased in probiotic-supplemented groups. Coliforms and total anaerobes counts were significantly reduced at 21 and 42 days at the ileum and caecal in $\mathrm{T}_{4}$, whereas the lactic acid bacteria (LAB) Lactobacilli count was significantly increased in all the probioticsupplemented groups. The results of the present study indicate that $L$. acidophilus at $10^{6} \mathrm{cfu} / \mathrm{g}$ feed inclusion in basal diet may improve blood biochemical parameters and histo-morphometry in the intestine and gut health in broiler chickens, resulting in a valid feed additive to replace antibiotic growth promoters.
\end{abstract}

Keywords: Feed additives, lactobacillus acidophilus, bifidobacterium bifidum gut health, histo-morphology, antibiotic

\#Corresponding author: drbiswas007@gmail.com

\section{Introduction}

In the last 50 years, antibiotic growth promoters (AGPs) have been used for intensive poultry production systems as feed additives to promote growth, production and feed conversion ratio through improving gut health and reducing sub-clinical infections (Barbieri et al., 2015). AGPs, however, are no longer permitted in most countries, owing to concern about antimicrobial resistance in birds and humans as consumers (Abudabos et al., 2017). In spite of their beneficial use, antibiotics are losing public image and their use is raising alarm owing to the emergence and spread of antibiotic resistant bacteria in recent years. Indeed, certain problems related to performance and health arises with the removal of feed antibiotics in broiler production (Sugiharto, 2016). There is increasing interest in finding alternatives to AGPs in poultry production systems (Seidavi et al., 2017), hence the search for different categories of feed additives for livestock animals, which are referred to as natural growth promoters, including probiotics, prebiotics, symbiotics, phytobiotics, feed enzymes and acidifiers (Tufarelli \& Laudadio, 2016). The dietary use of direct fed microbials, that is, probiotics, is one of the choices. These affect the host animal beneficially by improving its intestinal health (Yang et al., 2009). The abilities of probiotics to establish and maintain the balance of intestinal microbiota and improve the immunological competences and growth performances of broiler chickens have been acknowledged (Khan \& Naz, 2013). However, there is still some hesitation in the 
poultry industry over incorporating probiotics in broiler rations, since the results of in vivo experiments have been inconsistent (Sugiharto, 2016). Two major mechanisms of probiotic action are recommended. These include a nutritional effect by regulating metabolic reactions that produce toxic substances and stimulate endogenous enzymes, and by producing vitamins or antimicrobial substances (Jahromi et al., 2016). Broilers fed a mixture of Lactobacillus strains for 42 days improved in body weight gain and feed conversion ratio (Olnood et al., 2015). Therefore, the objective of the present study was to evaluate the effect of probiotics $L$. acidophilus and $B$. bifidum on blood biochemical parameters, intestinal histo-morphometry and gut health status of broiler chickens.

\section{Material and Methods}

Table 1 Composition of basal diet to which dietary supplementation of probiotics was added

\begin{tabular}{|c|c|c|c|}
\hline Ingredients (g/kg diet) & $\begin{array}{l}\text { Pre-starter } \\
\text { (0-14 days) }\end{array}$ & $\begin{array}{c}\text { Starter } \\
\text { (14-24 days) }\end{array}$ & $\begin{array}{c}\text { Finisher } \\
\text { (24-42 days) }\end{array}$ \\
\hline Maize, yellow & 491.25 & 515.65 & 582.85 \\
\hline Soybean meal (solvent extract) & 430.00 & 402.00 & 340.00 \\
\hline Rapeseed meal (solvent extract) & 30.00 & 30.00 & 30.00 \\
\hline Oil & 15.00 & 20.00 & 17.00 \\
\hline Limestone powder & 9.00 & 9.00 & 9.00 \\
\hline Di-calcium phosphate (DCP) & 17.00 & 16.00 & 14.00 \\
\hline Salt & 3.00 & 3.00 & 3.00 \\
\hline DL-Methionine & 1.60 & 1.20 & 1.00 \\
\hline *TM Premix-1 & 1.00 & 1.00 & 1.00 \\
\hline$\star \star$ Vit Premix-2 & 1.50 & 1.50 & 1.50 \\
\hline$\star \star \star B$. complex & 0.15 & 0.15 & 0.15 \\
\hline Choline Chloride & 0.50 & 0.50 & 0.50 \\
\hline \multicolumn{4}{|l|}{ Estimated value } \\
\hline Metabolizable energy (Kcal/kg) & 2895.89 & 2890.67 & 2950.30 \\
\hline Crude protein (\%) & 22.00 & 20.97 & 18.97 \\
\hline Total phosphorus \%) & 0.45 & 0.43 & 0.38 \\
\hline Total calcium (\%) & 1.01 & 0.98 & 0.91 \\
\hline Lysine (\%) & 1.24 & 1.16 & 1.01 \\
\hline Methionine & 0.54 & 0.50 & 0.44 \\
\hline Threonine & 0.98 & 0.93 & 0.84 \\
\hline
\end{tabular}

* Premix 1: Each g of mineral mixture contained $200 \mathrm{mg}$ ferrous sulphate $\left(\mathrm{FeSO}_{4} .7 \mathrm{H}_{2} \mathrm{O}\right), 20 \mathrm{mg}$ copper sulphate $\left(\mathrm{CuSO}_{4} .5 \mathrm{H}_{2} \mathrm{O}\right), 200 \mathrm{mg}$ manganese sulphate $\left(\mathrm{MnSO}_{4} \cdot \mathrm{H}_{2} \mathrm{O}\right), 150 \mathrm{mg}$ zinc sulphate $\left(\mathrm{ZnSO}_{4} .7 \mathrm{H}_{2} \mathrm{O}\right), 1 \mathrm{mg}$ potassium iodide $(\mathrm{KI})$

${ }^{* *}$ Premix 2: Each g of vitamin $A, B_{2}, D_{3}$ and $K$ (Spectromix, Ranboxy) provided vitamin A (retinol) 540 mg, vitamin $B_{2}$ (riboflavin) $50 \mathrm{mg}$, vitamin $\mathrm{D}_{3}$ (cholecalciferol) $400 \mathrm{mg}$, vitamin $\mathrm{K}$ (menadione) $10 \mathrm{mg}$.

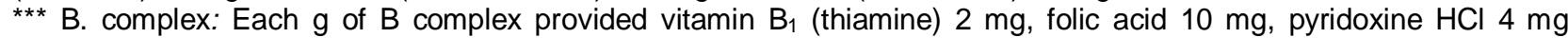
cyanocobalamin $10 \mu \mathrm{g}$, nicotinamide $12 \mathrm{mg}$

The present study was carried out at the Avian Nutrition and Feed Technology Division, Central Avian Research Institute, Izatnagar, India. Two hundred and forty day-old chicks were housed and distributed randomly in to 30 groups each of 8 chicks (6 treatments $\times 5$ replicates). The experiment had a complete randomized design (Snedecor \& Cochran, 1985). It was conducted strictly in accordance with the guidelines of the Institutional Animal Ethics Committee (IAEC) (18 September 2017/Project No. 11).

Six experimental diets $\left(T_{1}, T_{2}, T_{3}, T_{4}, T_{5}\right.$ and $\left.T_{6}\right)$ were formulated to contain 0 , bacitracin methyl di-salicylate (BMD) at $20 \mathrm{mg}$, L. acidophilus $\left(10^{6}\right.$ and $10^{7} \mathrm{cfu} / \mathrm{g}$ feed) and B. bifidum (10 ${ }^{6}$ and $10^{7} \mathrm{cfu} / \mathrm{g}$ feed, respectively). The basal diet $\left(T_{1}\right)$ and $B M D$ or probiotic-treated groups contained the same calculated energy 
(2901.3 metabolizable energy (ME)) and protein (19.5\% crude protein (CP)) (Junaid et al., 2018). $L$. acidophilus and $B$. bifidum (from M/s Unique Biotech, Hyderabad, Telangana, India) were used as a source of probiotic.

At the end of the feeding experiment (42 days), blood samples from 15 birds/treatment (3 birds /replicate) were randomly collected into sterile glass test tube without anticoagulant (Kumar, 2013). The test tubes containing the blood were kept in slanted position at room temperature for half an hour to facilitate the separation of serum. Serum was separated by centrifugation at $3000 \mathrm{rpm}$ for $10 \mathrm{~min}$ and decanted into plastic vials, then stored at $-20{ }^{\circ} \mathrm{C}$. Serum enzymes, that is, alkaline phosphatase (ALP, EC 3.1.3.1), aspartate aminotransferase (AST, EC 2.6.1.1) and alanine aminotransferase (ALT, EC 2.6.1.2) activities were estimated by spectrophotometry method (Bessay \& Lowry, 1946; Reitman \& Frankel, 1957). Kidney function test, that is creatinine and uric acid, minerals that is calcium and phosphorus were estimated according to Maxwell et al. (1990), while, total cholesterol total protein and albumin concentrations were measured by the methods of Wybenge et al., (1970), Lowry et al., (1951) and Guastaffson (1978), respectively

On days 21 and 42 five birds per treatment (total 60 birds) were used to measure VH under a highresolution microscope with micrometry and photographic attachment (Nikon Instruments Eclipse TS100 inverted microscope). A 1-cm segment of the midpoint of the ileum was removed, then the segments were washed with physiological saline solution, and fixed in $10 \%$ buffered formalin. Each segment was then embedded in paraffin, and a 2-mm section of each sample was placed on a glass slide and stained with haematoxylin and eosin for examination. Histological sections were examined microscopically. Villus height was measured from the top of the villus to the top of the lamina propria. Fifteen measurements were taken per bird for this variable. Differences between control and treatments were determined by t-test (Snedecor \& Cochran, 1985).

For microbial evaluation, the contents of the gastro intestinal tract (GIT) were squeezed from the ileum and caecal segments into sterile glass bottles on days 21 and 42. Three fresh samples $(1 \mathrm{~g})$ from each treatment were diluted and plated (using the method by Czerwinski et al., 2012) onto MacConkey agar, de Man, Rogosa and Sharpe agar and plate count agar to enumerate coliform, LAB, Lactobacilli spp. and total anaerobes, respectively. A general linear model was used on logarithmically valued counts to determine the effects of treatment and time on microbial levels (Czerwinski et al., 2012).

Data obtained in various studies were subjected to test of significance by SPSS-20 in a completely randomized design (Snedecor \& Cochran, 1985), and means were compared using Duncan's (Duncan, 1955) multiple range test at $P<0.05$.

\section{Results}

The results of the blood chemistry of broilers are presented in Table 2. There was no significant $(P$ $>0.05$ ) difference in serum total protein, albumin, mineral ( $\mathrm{Ca}$ and $\mathrm{P}$ ) concentrations and ALP activity in any of the dietary treatments. Significant increases $(P<0.05)$ were recorded in serum enzymes, that is, AST activity and creatinine concentration, whereas ALT, uric acid and total cholesterol concentration were significantly $(P<0.05)$ decreased in the probiotic-supplemented groups compared with the antibiotic and control groups.

The results of the present study are presented in Table 3. Villus height, VW, CD and VH: CD were significantly increased $(P<0.05)$ at 21 and 42 days in probiotics, that is, $L$. acidophilus-supplemented groups compared with other treated groups (Table 3 ).

The results of the present study (Table 4) indicated that coliforms and total anaerobe counts were significantly $(P<0.05)$ reduced at 21 and 42 days at the ileum and caecal in $T_{3}$ compared with other treatments, including the control, whereas lactic acid bacteria (LAB), lactobacilli count were significantly ( $P$ $<0.05)$ increased in all the probiotic-supplemented groups compared with control diet and antibiotic-treated group. The level of increase was higher in $L$. acidophilus than in B. bifidum.

\section{Discussion}

No significant differences were observed in total protein and albumin concentrations among the control, antibiotic-treated and probiotic-supplemented groups. The results of the present study are agreement with those of Owosibo et al. (2013), who reported that total protein and albumin concentration were not affected by probiotic supplementation in broiler chickens. However, the results obtained in this study for total protein and albumin concentration are contrary to those of other studies (Paryad \& Mahmoudi, 2008), which stated that the supplementation of probiotics in basal diet increased the protein and albumin concentration in broiler chickens. The results of the present study are in accord with the findings of Rahman et al. (2013), who stated that ALT values were decreased in probiotic-supplemented groups compared with the control and the antibiotic-treated group, but do not agree with those of Alkhalf et al. (2010), who reported 
Table 2 Effects of dietary supplementation of probiotics on serum biochemical parameters of broiler chickens

\begin{tabular}{|c|c|c|c|c|c|c|c|c|}
\hline \multirow{2}{*}{ Objects } & \multicolumn{6}{|c|}{ Diets } & \multirow{2}{*}{ SEM } & \multirow{2}{*}{$\begin{array}{c}P \text { - } \\
\text { value }\end{array}$} \\
\hline & T1 & T2 & T3 & T4 & T5 & T6 & & \\
\hline Protein (g/dL) & 4.34 & 4.26 & 4.49 & 4.43 & 4.81 & 4.56 & 2.17 & NS \\
\hline Albumin $(\mathrm{g} / \mathrm{dL})$ & 1.63 & 1.57 & 1.88 & 1.90 & 1.73 & 1.71 & 0.16 & NS \\
\hline Cholesterol (mg/dL) & $167.90^{\mathrm{b}}$ & $164.74^{\mathrm{b}}$ & $144.81^{a}$ & $149.63^{a}$ & $151.50^{\mathrm{a}}$ & $150.12^{\mathrm{a}}$ & 3.06 & $<0.05$ \\
\hline \multicolumn{9}{|l|}{ Serum enzymes } \\
\hline Alanine aminotransferase (IU/L) & $55.14^{b}$ & $51.22^{\mathrm{b}}$ & $42.17^{\mathrm{a}}$ & $44.49^{\mathrm{a}}$ & $50.25^{b}$ & $49.43^{\mathrm{ab}}$ & 0.17 & $<0.05$ \\
\hline Aspartate aminotransferase (IU/L) & $27.04^{\mathrm{a}}$ & $29.88^{\mathrm{a}}$ & $34.96^{\mathrm{b}}$ & $34.74^{\mathrm{b}}$ & $34.20^{\mathrm{b}}$ & $30.48^{\mathrm{ab}}$ & 0.30 & $<0.05$ \\
\hline Alkaline phosphatase (IU/L) & 210.86 & 207.17 & 216.65 & 214.03 & 183.38 & 186.27 & 5.14 & NS \\
\hline \multicolumn{9}{|l|}{ Kidney function test } \\
\hline Uric acid (mg/dL) & $1.52^{b}$ & $1.48^{\mathrm{b}}$ & $1.11^{\mathrm{a}}$ & $1.25^{\mathrm{a}}$ & $1.30^{\mathrm{a}}$ & $1.34^{\mathrm{a}}$ & 0.10 & $<0.05$ \\
\hline Creatinine $(\mathrm{mg} / \mathrm{dL})$ & $0.15^{\mathrm{abc}}$ & $0.40^{\mathrm{ab}}$ & $0.54^{\mathrm{a}}$ & $0.47^{\mathrm{ab}}$ & $0.43^{\mathrm{c}}$ & $0.45^{\mathrm{abc}}$ & 0.09 & $<0.05$ \\
\hline \multicolumn{9}{|l|}{ Serum minerals } \\
\hline Calcium (mg/dL) & 8. 28 & 8.19 & 8.54 & 8.65 & 8.73 & 8.51 & 0.28 & NS \\
\hline Phosphorus (mg/dL) & 5.11 & 5.01 & 5.23 & 5.08 & 5.15 & 5.07 & 0.24 & NS \\
\hline
\end{tabular}

Mean values bearing the same superscript in a row did not differ significantly $(P<0.05)$

T1: control; T2: antibiotic (bacitracin methyl di-salicylate- BMD) at $20 \mathrm{mg} / \mathrm{kg} \mathrm{diet;} \mathrm{T3:} \mathrm{Lactobacillus} \mathrm{acidophilus} \mathrm{(10}{ }^{6}$ cfu/g diet); T4: Lactobacillus acidophilus (107 cfu/g diet); T5: Bifidobacterium bifidum (10 ${ }^{6} \mathrm{cfu} / \mathrm{g}$ diet); T6: Bifidobacterium bifidum $\left(10^{7} \mathrm{cfu} / \mathrm{g}\right.$ diet $)$

Table 3 Effects of dietary supplementation of probiotics on the intestinal histo-morphometry in broiler chickens

\begin{tabular}{|c|c|c|c|c|c|c|c|c|}
\hline \multirow{2}{*}{ Objects } & \multicolumn{6}{|c|}{ Diets } & \multirow{2}{*}{ SEM } & \multirow{2}{*}{$P$-value } \\
\hline & T1 & T2 & T3 & T4 & T5 & T6 & & \\
\hline \multicolumn{9}{|c|}{21 days } \\
\hline Villus height $(\mu \mathrm{m})$ & $742.13^{a b}$ & $743.77^{\mathrm{ab}}$ & $787.93^{\mathrm{C}}$ & $746.73^{\mathrm{ab}}$ & $765.90^{\mathrm{bc}}$ & $759.77^{b}$ & 14.36 & $<0.05$ \\
\hline Villus width $(\mu \mathrm{m})$ & $74.56^{\mathrm{a}}$ & $76.34^{\mathrm{a}}$ & $87.90^{\mathrm{C}}$ & $86.54^{\mathrm{bc}}$ & $86.34^{\mathrm{bc}}$ & $85.40^{\mathrm{bc}}$ & 3.81 & $<0.05$ \\
\hline Crypt depth $(\mu \mathrm{m})$ & $152.83^{a}$ & $144.34^{\mathrm{a}}$ & $173.17^{c}$ & $159.84^{b}$ & $162.67^{c}$ & $156.67^{b}$ & 4.35 & $<0.05$ \\
\hline $\mathrm{VH}: \mathrm{CD}$ & $4.86^{\mathrm{ab}}$ & $5.15^{\mathrm{b}}$ & $4.55^{\mathrm{a}}$ & $4.67^{\mathrm{ab}}$ & $4.71^{a b}$ & $4.85^{\mathrm{ab}}$ & 0.12 & $<0.05$ \\
\hline \multicolumn{9}{|c|}{42 days } \\
\hline Villus height $(\mu \mathrm{m})$ & $1093.93^{\mathrm{a}}$ & $1079.04^{a}$ & $1281.50^{C}$ & $1165.47^{b}$ & $1274.73^{C}$ & $1157.69^{b}$ & 18.48 & $<0.05$ \\
\hline Villus width $(\mu \mathrm{m})$ & $98.59^{\mathrm{ab}}$ & $99.54^{\mathrm{ab}}$ & $123.73^{b}$ & $111.57^{\mathrm{ab}}$ & $110.75^{\mathrm{ab}}$ & $107.94^{\mathrm{ab}}$ & 4.17 & $<0.05$ \\
\hline Crypt depth $(\mu \mathrm{m})$ & $207.00^{b}$ & $190.00^{a}$ & $264.33^{d}$ & $240.00^{c}$ & $247.00^{c}$ & $235.83^{c}$ & 8.10 & $<0.05$ \\
\hline $\mathrm{VH}: \mathrm{CD}$ & $5.28^{b}$ & $5.68^{b}$ & $4.85^{\mathrm{a}}$ & $4.86^{\mathrm{a}}$ & $5.16^{b}$ & $4.91^{\mathrm{a}}$ & 0.08 & $<0.05$ \\
\hline
\end{tabular}

Mean values bearing the same superscript in a row did not differ significantly $(P<0.05)$

VH: villus height; WW: villus width; CD: crypt depth

T1: control; T2: antibiotic (bacitracin methyl di-salicylate- BMD) at $20 \mathrm{mg} / \mathrm{kg}$ diet; T3: Lactobacillus acidophilus (10 ${ }^{6}$ cfu/g diet); T4: Lactobacillus acidophilus (10 cfu/g diet); T5: Bifidobacterium bifidum (106 $\mathrm{cfu} / \mathrm{g}$ diet); T6: Bifidobacterium bifidum $\left(10^{7} \mathrm{cfu} / \mathrm{g}\right.$ diet $)$ 
Table 4 Effects of dietary supplementation of probiotics on the gut health status in broiler chickens

\begin{tabular}{|c|c|c|c|c|c|c|c|c|}
\hline \multirow{2}{*}{ Objects } & \multicolumn{6}{|c|}{ Diets } & \multirow{2}{*}{ SEM } & \multirow{2}{*}{$P$-value } \\
\hline & T1 & T2 & T3 & T4 & T5 & T6 & & \\
\hline \multicolumn{9}{|c|}{21 days } \\
\hline \multicolumn{9}{|l|}{ Ileum } \\
\hline Coliform & $3.54^{\mathrm{b}}$ & $3.11^{\mathrm{a}}$ & $3.17^{\mathrm{a}}$ & $3.24^{\mathrm{a}}$ & $3.38^{\mathrm{ab}}$ & $3.40^{\mathrm{ab}}$ & 0.18 & $<0.05$ \\
\hline Total anaerobes & $6.99^{b}$ & $6.13^{\mathrm{a}}$ & $6.20^{\mathrm{a}}$ & $6.56^{a b}$ & $6.58^{\mathrm{ab}}$ & $6.65^{\mathrm{ab}}$ & 0.11 & $<0.05$ \\
\hline${ }^{*} \mathrm{LAB}$ & $6.36^{\mathrm{a}}$ & $6.10^{\mathrm{a}}$ & $7.19^{b}$ & $6.83^{a b}$ & $6.67^{\mathrm{ab}}$ & $6.75^{\mathrm{ab}}$ & 0.21 & $<0.05$ \\
\hline Lactobacilli & $6.82^{\mathrm{ab}}$ & $6.59^{a}$ & $7.28^{b}$ & $7.07^{\mathrm{b}}$ & $7.02^{b}$ & $6.99^{\mathrm{ab}}$ & 0.16 & $<0.05$ \\
\hline \multicolumn{9}{|l|}{ Caeca } \\
\hline Coliform & $4.35^{\mathrm{b}}$ & $3.60^{\mathrm{ab}}$ & $3.32^{\mathrm{a}}$ & $3.47^{\mathrm{a}}$ & $3.58^{\mathrm{ab}}$ & $3.64^{\mathrm{ab}}$ & 0.43 & $<0.05$ \\
\hline Total anaerobes & $7.60^{b}$ & $7.16^{\mathrm{a}}$ & $7.14^{\mathrm{a}}$ & $7.29^{a b}$ & $7.34^{\mathrm{ab}}$ & $7.33^{\mathrm{ab}}$ & 0.92 & $<0.05$ \\
\hline${ }^{*} \mathrm{LAB}$ & $7.05^{\mathrm{a}}$ & $6.74^{\mathrm{a}}$ & $7.57^{\mathrm{b}}$ & $7.26^{\mathrm{b}}$ & $7.38^{\mathrm{b}}$ & $7.33^{b}$ & 0.67 & $<0.05$ \\
\hline Lactobacilli & $7.53^{\mathrm{ab}}$ & $7.08^{\mathrm{a}}$ & $7.79^{b}$ & $7.63^{\mathrm{ab}}$ & $7.70^{\mathrm{b}}$ & $7.56^{\mathrm{ab}}$ & 0.18 & $<0.05$ \\
\hline \multicolumn{9}{|c|}{42 days } \\
\hline \multicolumn{9}{|l|}{ Ileum } \\
\hline Coliform & $4.75^{\mathrm{b}}$ & $4.02^{\mathrm{a}}$ & $4.11^{\mathrm{a}}$ & $4.36^{\mathrm{ab}}$ & $4.30^{\mathrm{ab}}$ & $4.42^{\mathrm{ab}}$ & 0.19 & $<0.05$ \\
\hline Total anaerobes & $7.72^{\mathrm{ab}}$ & $7.12^{\mathrm{a}}$ & $7.15^{a}$ & $7.27^{\mathrm{a}}$ & $7.24^{\mathrm{a}}$ & $7.38^{\mathrm{ab}}$ & 0.18 & $<0.05$ \\
\hline${ }^{*} \mathrm{LAB}$ & $7.51^{b}$ & $6.85^{\mathrm{a}}$ & $7.86^{b}$ & $7.45^{\mathrm{b}}$ & $7.66^{b}$ & $7.36^{\mathrm{b}}$ & 0.32 & $<0.05$ \\
\hline Lactobacilli & $8.19^{b c}$ & $7.72^{\mathrm{a}}$ & $8.54^{c}$ & $8.42^{b c}$ & $8.40^{\mathrm{bc}}$ & $8.36^{\mathrm{bc}}$ & 0.17 & $<0.05$ \\
\hline \multicolumn{9}{|l|}{ Caeca } \\
\hline Coliform & $5.42^{b}$ & $4.59^{\mathrm{a}}$ & $4.40^{\mathrm{a}}$ & $4.66^{\mathrm{ab}}$ & $4.70^{\mathrm{ab}}$ & $4.87^{\mathrm{ab}}$ & 0.3 & $<0.05$ \\
\hline Total anaerobes & $8.81^{\mathrm{ab}}$ & $8.08^{\mathrm{a}}$ & $8.16^{a}$ & $8.27^{\mathrm{a}}$ & $8.63^{\mathrm{ab}}$ & $8.44^{\mathrm{ab}}$ & 0.70 & $<0.05$ \\
\hline${ }^{*} \mathrm{LAB}$ & $8.30^{\mathrm{cd}}$ & $7.56^{\mathrm{ab}}$ & $8.78^{a}$ & $8.47^{\mathrm{ab}}$ & $8.57^{\mathrm{bc}}$ & $8.45^{\mathrm{cd}}$ & 0.51 & $<0.05$ \\
\hline Lactobacilli & $8.33^{b}$ & $7.58^{\mathrm{a}}$ & $8.62^{b}$ & $8.50^{b}$ & $8.56^{b}$ & $8.45^{\mathrm{b}}$ & 0.15 & $<0.05$ \\
\hline
\end{tabular}

Mean values bearing the same superscript in a row did not differ significantly $(P<0.05)$

*LAB: lactic acid bacteria

T1: control; T2: antibiotic (bacitracin methyl di-salicylate- BMD) at $20 \mathrm{mg} / \mathrm{kg}$ diet; T3: Lactobacillus acidophilus (10 ${ }^{6}$ cfu/g diet); T4: Lactobacillus acidophilus (10 cfu/g diet); T5: Bifidobacterium bifidum (106 cfu/g diet); T6: Bifidobacterium bifidum $\left(10^{7} \mathrm{cfu} / \mathrm{g}\right.$ diet)

no significant role of dietary probiotic inclusion. On the other hand, AST activity increased significantly $(P$ $<0.05)$ in the entire dietary probiotic-supplemented group. The results are not in agreement with the findings of Rahman et al. (2013) and Owosibo et al. (2013), who found no significant difference in ALT and AST activities after supplementation of dietary probiotics in broiler chickens. A significant $(P<0.05)$ decrease in the total cholesterol concentration was recorded when the basal diet was supplemented with probiotics L. acidophilus and B. bifidum. Similarly, Hatab et al. (2016) reported that the inclusion of probiotics in diets reduced the cholesterol concentration in broiler chickens. It was also stated that some microorganisms in the preparation of probiotics could utilize cholesterol in the GIT for their own metabolism, thus might reduce the absorption of cholesterol (Al-Kassie et al., 2008). Cholesterol may also be metabolized to ergosterol by bacteria in the gut. The mechanism by which probiotics eliminate cholesterol would probably be through reducing lipid absorption in the intestine by binding bile acids, which results in increased cholesterol elimination and hepatic synthesis of new bile acid (Hashemzadeh et al., 2013). Jouybari et al. (2010) reported that the use of probiotic in the rations of broiler chickens significantly reduced the serum cholesterol level compared with the control $(P<0.05)$. In contrast, Yalcinkaya et al. (2008) reported that the use of probiotic in broiler diets could not significantly reduce the serum cholesterol and triglyceride levels compared with the control group. The synthesis of bile acids from cholesterol in the liver is the most important way of excreting cholesterol (Jouybari et al., 2010). Moreover, probiotics possibly degenerate bile salts, de-conjugate the production of enzymes by the activity of $L A B$ and decrease the $\mathrm{pH}$ in the intestinal tract, which might be conducive to decreasing cholesterol absorption (Hatab et al., 2016). Miscibility of non- 
conjugate bile acids might be lower at a low $\mathrm{pH}$ and accordingly cholesterol is absorbed less from the intestine and emitted more through faeces. Subsequently, the liver, to compensate for the hepatic cycle of bile acids, coverts more cholesterol concentration into the tissues, resulting in the reduction of cholesterol concentrations in the blood (Salarmoini \& Fooladi, 2011).

Serum uric acids usually reflect the functioning of the kidney. The results of the present study found that uric acid concentration was significantly decreased in the probiotic group. Due to decrease in serum uric acid was at tolerance level, no gross abnormalities were found in the kidneys of probiotic-treated birds. The uric acid concentration in the present study was not consistent with the findings of Sultan \& Abdul-Rahman (2011) and Salahuddin et al. (2013), who detected an increase in uric acid with a rise in the level of probiotic supplementation in broiler chickens. On the other hand, creatinine level was significantly increased in the broilers that received probiotics in their diet compared with birds fed on antibiotic and basal rations. The present findings are not in agreement with the observations of Owosibo et al. (2013) and Salim et al. (2011), who reported that supplementation of diet with probiotics had no role in an increase or decrease in serum creatinine level in broiler chickens. However, Magdel-din et al. (2015) reported significant reductions in uric acid, but an increase in creatinine in chicks provided probiotics in their diet compared with those fed on antibiotics in a basal diet.

According to Panda et al. (2003), the addition of probiotics increased serum calcium significantly. They stated that serum phosphorus level was not influenced by supplementation with probiotics. The results of the present study agree partially with these findings. The current results suggested that the addition of probiotics had no significant effect on serum calcium and phosphorus concentrations, but these results do not agree with the findings of Gilman \& Cashman (2006), who reported that the concentration of calcium was significantly higher after the application of a probiotics strain. The results of serum calcium and phosphorus showed that the chicks fed a probiotic-supplemented diet had a higher concentration compared with chicks fed a control diet, which could be because the acidic anion complex with the calcium and cationic minerals resulted in an improvement in digestibility of these minerals, as reported by several workers (El-Baky, 2013).

In the present study, probiotics appeared to influence the micro-structure of the gut more consistently. It showed that probiotics affected VH : CD in the ileum significantly $(P<0.05)$ compared with control diets. This indicates that the absorptive function in the ileum of these chickens was higher compared with control treatments. Iji et al. (2001) found that at day 21, the ileal villi were significantly longer in chickens fed a less viscous diet, although they did not differ in the first seven days of the experiment. The intestine can change its surface area by growing in length, and by increasing or decreasing the height of its villi when probiotics are supplied in the diet. Shortening and fusion of villi result in loss of surface area for digestion and absorption of food (Van Der Wielen et al., 2002), whereas the converse is true of longer villi and shallower crypts (Bai et al., 2013). The GIT has the ability to adapt or react morphologically to changing conditions, such as altered diet (Strompfová et al., 2006). It is well known that dietary probiotics lead to marked changes in the gut microflora, often favouring the host.

The current study showed that enterobacteria made up only a minor proportion of the total ileal and caecal microflora in broilers on days 21 and 42. Probiotics supplementation reduced the population of enterobacteria in the ileum and caeca compared with the control. This is in agreement with the findings of Mountzouris et al. (2010), who reported that supplementation with a probiotic strain of $L$. reuteri significantly reduced the number of enterobacteria in broiler chickens. A similar finding was recorded by Lan et al. (2003) after the birds fed diets that included with a mixture of L. acidophilus, I. gallinarum, L. agilis, L. salivarius and Lactobacillus spp. Cao et al. (2013) reported that broiler chickens fed diets supplemented with Lactobacilli spp. were more resistant to the pathogenic effects of coliform. The antimicrobial effects of probiotics come from the volatile fatty acid and other organic acids such as lactate and succinate (Kubena et al., 2001) and through the production of bacteriocins and phage-displayed peptides (Sakai et al., 2006).

In the present study, an increase was observed in the number of Lactobacilli in the ileum and caeca on days 21 and 42. Although, the population of lactobacilli was larger in the ileal and caecal contents of the treatment groups fed probiotic supplements, the current study does not demonstrate an improvement in growth performance of birds. The impact of lactobacilli on animal health and performance is controversial. Many Lactobacillus spp. act via a number of mechanisms, including competitive exclusion, to reduce the number of pathogens in the GIT, leading to improvement in bird performance (Schneitz \& Hakkinen, 1998). Other species seem to be neutral in their effects on bird performance (Gunal et al., 2006). However, it is imaginable that the antagonism for nutrients by a large number of lactobacilli in the GIT of birds may offset some or all of the beneficial effects of probiotics on nutrient digestibility and absorption. 


\section{Conclusions}

It is concluded from this study that inclusion of $L$. acidophilus at $10^{6} \mathrm{cfu} / \mathrm{g}$ basal diet improved blood biochemical parameters, histo-morphometry of intestine, and gut health of broiler chickens and may therefore be an alternative to AGPs.

\section{Acknowledgements}

The study was funded by the Department of Biotechnology, Ministry of Science and Technology, Govt. of India

\section{Authors' Contributions}

$A B$ designed the study, carried out the animal experiment, and manuscript drafting, JN, KM and QS carried out the animal experiment and conducted the laboratory analysis and ABM carried out the data analysis and final drafting.

\section{Ethical Standard}

All institutional and national guidelines for the care and use of laboratory animals were followed.

\section{Conflict of Interest Declaration}

The authors declare that they have no competing interests.

\section{References:}

Abudabos, A.M., Alyemni, A.H., Dafalla, Y.M. \& Khan, R.U., 2017. The effect of phytogenics on growth traits, blood biochemical and intestinal histology in broiler chickens exposed to Clostridium perfringens challenge. J. Appl. Anim. Res. 46, 691-695 (doi.org/10.1080/ 09712119.2017.1383258).

Al-Kassie, G.A.M., Al-Jumaa, Y.M.F. \& Jameel, Y.J., 2008. Effect of probiotic (Aspergillus niger) and prebiotic (Taraxacum officinale) on blood picture and biochemical properties of broiler chicks. Int. J. Poult. Sci. 7, 11821184. (doi:10.3923/ijps.2008.1182.1184).

Alkhalf, A., Alhaj, M. \& Al-Homidan, I., 2010. Influence of probiotic supplementation on blood parameters and growth performance in broiler chickens. Saudi J. Biol. Sci. 17, 219-225 (doi: 10.1016/j.sjbs.2010.04.005).

Bai, S.P., Wu, A.M., Ding, X.M., Lei, Y., Bai, J., Zhang, K.Y. \& Chio, J.S., 2013. Effects of probiotic-supplemented diets on growth performance and intestinal immune characteristics of broiler chickens. Poult. Sci. 92, 663-670 (doi: org/ 10.3382/ps.2012-02813).

Barbieri, A., do Valle Polycarpo, G., Cardoso, R.G.A., da Silva, K.M., Dadalt, J.C., Madeira, A.M.B.N., de Sousa, R.L.M., de Albuquerque, R. \& Cruz-Polycarpo, V.C., 2015. Effect of probiotic and organic acids in an attempt to replace the antibiotics in diets of broiler chickens challenged with Eimeria spp. Int. J. Poult. Sci. 14, 606-614. (doi:10.3923/ijps.2015.606.614).

Bessay, O.A. \& Lowry, O.H., 1946. A method for rapid determination of alkaline phosphatase with 5 cubic millimeters of serum. J. Biol. Chem. 64, 321-329.

Cao, G.T., Zeng, X.F., Chen, A.L., Zhou, G., Zhang, L. \& Xiao, Y.P., 2013. Effects of a probiotic, enterococcus faecium, on growth performance, intestinal morphology, immune response, and cecal microflora in broiler chickens challenged with Escherichia coli. Poult. Sci. 92, 2949-2955. (doi.org/10.3382/ps.2013-03366).

Czerwinski, J.O., Hojberg, S., Smulikowska, R.M., Engberg \& Mieczkowska, A., 2012. Effects of sodium butyrate and salinomycin upon intestinal microbiota, mucosal morphology and performance of broiler chickens. Arch. Anim. Nutr. 66, 102-116. (doi.org/10.1080/ 1745039X. 2012.663668).

Duncan, B.D., 1955. Multiple range and multiple $\mathrm{F}$ tests. Biometrics 11, 1-12.

El-Baky, A.A.A., 2013. Clinico-pathological and immunological effects of multistrain probiotic on broiler chicken vaccinated against avian influenza virus. Global Vet. 10, 534-541.

Gilman, J. \& Cashman, K.D., 2006. The effect of probiotic bacteria on transepithelial calcium transport and calcium uptake in human intestinal-like Caco-2 cells. Intestinal Microbiol. 7(1), 1-5.

Guastaffson, J.E., 1978. Automated serum albumin determination by use of the immediate reaction with bromocresol green reagent. Clin. Chem. 24, 2369-2373.

Gunal, M., Yayli, G., Kaya, O., Karahan, N. \& Sulak, O., 2006. The effects of antibiotic growth promoter, probiotic or organic acid supplementation on performance, intestinal microflora and tissue of broiler. Int. J. Poult. Sci. 5, 149-155. (doi: 10.3923/ijps.2006.149.155).

Hashemzadeh, F., Shaban, R., Mohammad, A., Karimi, T. \& Ali-Akbar, M., 2013. Effects of probiotics and antibiotic supplementation on serum biochemistry and intestinal microflora in broiler chicks. Int. J. Agri. Crop Sci. 5, 2394-2398.

Hatab, M.H., Elsayed, M.A. \& Ibrahim, N.S., 2016. Effect of some biological supplementation on productive performance, physiological and immunological response of layer chicks. J Radiation Res. Appl. Sci. 9(2), 185-192. (doi.org/10.1016/j.jrras.2015.12.008).

Iji, P.A., Saki, A.A. \& Tivev, D.R., 2001. Intestinal development and body growth of broiler chicks on diets supplemented with non-starch polysaccharides. Anim. Feed Sci. Technol. 89, 175-188.

Jahromi, M.F., Altaher, Y.W., Shokryazdan, P., Ebrahimi, R., Ebrahimi, M., Idrus, Z., Tufarelli, V. \& Liang, J.B., 2016. Dietary supplementation of a mixture of Lactobacillus strains enhances performance of broiler chickens raised under heat stress conditions. Int. J. Biometerol. 60 (7), 1099-1110 (doi. 10.1007/s00484-015-1103-x). 
Jouybari, M.G., Malbobi, M.A., Irani, M. \& Pour, V.R., 2010. The effect of novel probiotic on performance and serum concentration of cholesterol and triglycerides in broiler chicken. Afr. J. Biotech. 9, 7771-7774. (doi.org/10.5897/AJB2010.000-3314).

Junaid, N., Biswas, A., Kumawat, M. \& Mandal, A.B., 2018. Production performance, immune response and carcass traits of broiler chickens fed diet incorporated with probiotics. Indian J. Anim. Res. (online). Doi: 10.18805/ijar.B3420.

Khan, R.U. \& Naz, S., 2013. Application of probiotics in poultry production. Wrld's Poult. Sci. J. 69, 621-632. (doi: 10.1017/S0043933913000627).

Kubena, L.F., Bailey, R.H., Byrd, J. A., Young, C.R., Corrier, D.E. \& Stanker, L.H., 2001. Cecal volatile fatty acids and broiler chick's susceptibility to Salmonella typhimurium, colonization as affected by aflatoxins and T-2 toxin. Poult. Sci. 80,411-417.

Kumar, P., Biswas, A., Bharti, V.K. \& Srivastava, R.B., 2013. Effects of dietary copper supplementation on performance and blood biochemical parameters in broiler chickens at cold desert region in India. J. Vet. Sci. 114, $166-172$.

Lan, P.T.N., Binh, L.T. \& Benno, Y., 2003. Impact of two probiotic Lactobacillus strains feeding on faecal lactobacilli and weight gains in chicken. J. Gen. Appl. Microbiol, 49, 29-36. (doi.org/10.2323/jgam.49.29).

Lowry, O.H., Rosebrough, N.J., Farr, A.L. \& Randall, R.J., 1951. Protein measurement with the folin phenol reagent. J. Biol. Chem. 193, 265-275.

Magdel-Din, M.H., Mohamed, F.G., Mona, Y.O., Al-Shimaa, G.S. \& Mohamed, M.I.H., 2015. Production and prebiotic activity of exopolysaccharides derived from some probiotics. Egyptian Pharmaceutical J. 14, 1-9. (doi:10.4103/1687-4315.154687).

Maxwell, M.H., Spence, S., Robertson, G.W. \& Mitchell, M.A., 1990. Haematological and morphological responses of broiler chicks to hypoxia. Avian Pathol. 19, 23-40.

Mountzouris, K.C., Tsitrsikos, P., Palamidi, I., Arvaniti, A., Mohnl, M., Schatzmayr, G. \& Fegeros, K., 2010. Effects of probiotic inclusion levels in broiler nutrition on growth performance, nutrient digestibility, plasma immunoglobulins, and cecal microflora composition. Poult. Sci. 89, 58-67. (doi: 10.3382/ps.2009-00308).

Olnood, C.G., Beski, S.S.M., Choct, M. \& Iji, P.A., 2015. Novel probiotics: their effects on growth performance, gut development, microbial community and activity of broiler chickens. Anim. Nutr. 1, 184-191. (doi: 10.1016/j.aninu.2015.07.003).

Owosibo, A.O., Odetola, O.M., Odunsi, O.O., Adejinmi, O.O. \& Lawrence, A.O.O., 2013. Growth, haematology and serum biochemistry of broilers fed probiotics based diets. Afr. J. Agric. Res. 8(41), 5076-5081. (doi.org/10.5897/AJAR2013.7593).

Panda, A.K., Reddy, M.R., Ramarao, S.V. \& Praharaj, N.K. 2003. Production performance, serum/yolk cholesterol and immune competence of white leghorn layers as influenced by dietary supplementation with probiotic. Trop. Anim. Health Prod. 35, 85-94. (doi: 10.1023/A: 1022036023325).

Paryad, A. \& Mahmoudi. M., 2008. Effect of different levels of supplemental yeast (Saccharomyces cerevisiae) on performance, blood constituents and carcass characteristics of broiler chicks. Afr. J. Agric. Res. 3, 835-842.

Rahman, M., Mustari, A., Salauddin, M. \& Rahman, M., 2013. Effects of probiotics and enzymes on growth performance and haematobiochemical parameters in broilers. J. Bangladesh Agric. University, 11(1), 111-118. (doi.org/10.3329/jbau.v11i1.18221).

Reitman, S. \& Frankel, S., 1957. A colorimetric method for the determination of serum glutamic oxalacetic and glutamic pyruvic transaminases. Am. J. Clin. Pathol. 28, 56-63.

Sakai, Y., Tsukahara, T., Matsubara, N. \& Ushida, K., 2006. A cell wall preparation of Enterococcus faecalis strain EC-12 stimulates $\beta$-defensin expression in newly hatched broiler chicks. Anim. Sci. J. 78, $92-97$ (doi: 10.1111/j.17400929.2006.00410.x).

Salahuddin, M., Akhter, H., Akter, S., Miah, M.A. \& Ahmad, N., 2013. Effects of probiotics on haematology and biochemical parameters in mice. The Bangladesh Vet. 30 (1), 20-24. (doi: http://dx.doi.org/10.3329/bvet.v30i1.16281).

Salarmoini, M. \& Fooladi, M.H., 2011. Efficacy of Lactobacillus acidophilus as probiotic to improve broiler chicks performance. J. Agri. Sci. Technol. 13,165-172.

Salim, H.A., Abd-Allah, O.A. \& Fararh, K.M., 2011. Effect of feeding probiotic on hematological, biochemical properties and immune response in broiler. Benha Vet. Med. J. 22:35-43.

Schneitz, C. \& Hakkinen, M., 1998. Comparison of two different types of competitive exclusion products. Letters Appl. Microbiol. 26, 338-341.

Seidavi, A., Dadashbeiki, M., Alimohammadi-Saraei, M.H., Van den Hoven, R., Payan-Carreira, R., Laudadio, V. \& Tufarelli, V., 2017. Effects of dietary inclusion level of a mixture of probiotic cultures and enzymes on broiler chickens immunity response. Environ. Sci. Pollution Res. 24(5), 4637-4644. (DOI: 10.1007/s11356-016-8206-8).

Snedecor, G.W. \& Cochran, G.W., 1985. Statistical Methods. $8^{\text {th }}$ Ed. The lowa State University Press, Iowa; U.S.A.

Strompfova, V., Marcinakova, M., Simonova, M., Gancarcíkova, S., Jonecova, Z., Scirankova, L., Koscova, J., Buleca, V., Cobanova, K. \& Laukova, A., 2006. Enterococcus faecium EK13 - an enterocin A producing strain with probiotic character and its effect in piglets. Anaerobe 12, 242-248.

Sugiharto, S., 2016. Role of nutraceuticals in gut health and growth performance of poultry. J. Saudi Soc. Agric. Sci. 15, 99-111. (doi.org/10.1016/j.jssas.2014.06.001).

Sultan, K.H. \& Abdul-Rahman, S.Y., 2011. Effect of probiotic on some physiological parameters in broiler breeders. Int. J. Poult. Sci. 10, 626-628. (DOI: 10.3923/ijps.2011.626.628).

Tufarelli, V. \& Laudadio, V., 2016. An overview on the functional food concept: prospective and applied researches in probiotics, prebiotics and synbiotics. J. Exp. Biol. Agric. Sci. 4, 274-278. (doi:org/10.18006/2016.4(3S).273.278). 
Van-Der Wielen, P.W.J.J., Lipman, L.J.A., Vanknapen, F. \& Biesterveld, S., 2002. Competitive exclusion of Salmonella enterica serovar enteritidis by Lactobacillus crispatus and Clostridium lactate fermentans in a sequencing fedbatch culture. J. Appl. Environ. Microbiol. 68, 555-559.

Wybenge, D.R., Pileggi, V.J, Dirstine, H. \& Giorgio, J.D., 1970. Direct manual determination of serum total cholesterol with a single stable reagent. Clin. Chem. 16, 980-984.

Yalcinkaya, H., Gungori, T., Bafialani, M. \& Erdem, E., 2008. Mannan oligosaccharides (MOS) from Saccharomyces cerevisiae in broilers: effects on performance and blood biochemistry. Turkish J. Vet. Anim. Sci. 32 (1), 43-48.

Yang, Y., lji, P.A. \& Choct, M., 2009. Dietary modulation of gut microflora in broiler chickens: a review of the role of six kinds of alternatives to in-feed antibiotics. Wrld's Poult. Sci. J. 65, 97-114. (doi.org/10.1017/S0043933909000087). 